\title{
Aplikasi Trigona (Tetragonula) laeviceps sebagai Agen Penyerbuk pada Sistem Tumpang Sari Buncis dan Tomat di dalam Rumah Kaca
}

\author{
Application of Trigona (Tetragonula) laeviceps as Pollinator of \\ Mixed Crops Plantation of Beans and Tomatoes in Greenhouse
}

\author{
SOVIA SANTI LEKSIKOWATI, RAMADHANI EKA PUTRA ${ }^{2 *}$, MIA ROSMIATI ${ }^{2}$, IDA KINASIH ${ }^{3}$, INAYATI \\ ZAKIYATUN HUSNA ${ }^{2}$, NOVITASARI ${ }^{2}$, EKA SETIYARNI ${ }^{2}$, FAJRINA ANJARNISA RUSTAM ${ }^{2}$
}

\author{
${ }^{1}$ Program Studi Biologi, Institut Teknologi Sumatera, Jl. Terusan Ryacudu, Lampung 35365 \\ ${ }^{2}$ Program Studi Rekayasa Pertanian, Laboratorium Teknik 1A, Sekolah Ilmu dan Teknologi Hayati, Institut Teknologi \\ Bandung, Jl. Let. Jend. Purn. Dr. (HC) Mashudi, Kampus Jatinangor, Sumedang 45363 \\ ${ }^{3}$ Jurusan Biologi, Fakultas Sains dan Teknologi, Universitas Islam Negeri Sunan Gunung Djati Bandung, Jl. AH \\ Nasution, Bandung 40614
}

Diterima 30 March 2018/Disetujui 18 June 2018

\begin{abstract}
Greenhouse widely applied to provides protection against pest and harsh environment condition and most farmers usually planted mixed crops inside. However, this system creates an isolation to pollination which responsible for fruit production. In this study, local domesticated stingless bees, Trigona (Tetragonula) laeviceps, was applied as pollinator for two crops, beans (Phaseolus vulgaris L.) and tomatoes (Solanum lycopersicum $\mathbf{L}$.) planted as mixed crops inside greenhouse. The benefit of the bees was measured as pollination success and quality of the crops produced (size and weight). Tomato flowers received no visit from both wild pollinators (all was Apis cerana) and stingless bees while in bean flowers, A. cerana exhibited more and longer visits to flower than $T$. laeviceps albeit lower number of flowers visited. The pollination efficiency between wild pollinator and $T$. laeviceps for beans (both at $41 \%$ ) while self pollination produced better pollination efficiency for tomatoes planted at open field ( $84 \%$ compared to $71 \%)$. Beans planted at open field produced better products (bigger size and heavier) while tomatoes produced lesser quality although the differences were not significant. Based on this study, T. laeviceps may applied as pollinator agent in greenhouse and for mixed crops of beans and tomatoes.
\end{abstract}

Key words: stingless bees, pollination, mixed crops, greenhouse

\section{PENDAHULUAN}

Jawa Barat merupakan salah satu sentra pertanian utama di Indonesia dengan tanaman sayuran (BPS 2018). Produksi sayuran di Jawa Barat banyak ditopang oleh produksi dari para petani dengan lahan garapan kecil yang seringkali melakukan sistem pertanian tumpang sari dengan tujuan untuk produktivitas lahan (Adiyoga et al. 2004). Sistem pertanian ini sendiri sangat tergantung pada jasa ekosistem dalam meningkatkan produktivitas dari produk yang dihasilkan. Jasa ini sendiri sangat bergantung pada agen-agen hayati yang memberikan jasa tersebut. Salah satu agen hayati paling penting terkait dengan jasa ekosistem adalah serangga yang dapat memberikan beberapa jasa

*Penulis korespondensi:

E-mail: ramadhani@sith.itb.ac.id utama pada sistem pertanian seperti pengendalian hama, siklus nutrisi, dan penyerbukan (Ricketss 2004; Tscharntke et al. 2005; Winfree et al. 2008). Penyerbukan sebagai salah satu jasa yang paling berkaitan dengan kesinambungan dari produktivitas sistem pertanian (Klein et al. 2007). Diduga sekitar $70 \%$ tanaman budidaya di dunia bergantung pada agen penyerbukan untuk proses penyerbukan mereka (Breeze et al. 2016) dengan nilai ekonomi hingga 153-285 milyar Euro per tahun (Klein et al. 2007; Jacquemin et al. 2017).

Akan tetapi seriring dengan peningkatan tekanan bagi petani untuk menghasilkan lebih banyak produk bagi pemenuhan kebutuhan pasar, maka aktivitas pertanian di sebagian sentra produksi pertanian mulai menerapkan intensifikasi dan penyederhanaan sistem pertanian yang dapat memberikan tekanan besar pada diversitas dan kelimpahan dari seranggaserangga liar yang berperan sebagai agen penyerbuk 
(Tscharntke et al. 2005; Biesmeijer et al. 2006; Winfree et al. 2008; Potts et al. 2010; Cameron et al. 2011; Carvalheiro et al. 2013; Potts et al. 2016). Kehilangan serangga-serangga penyerbuk liar ini dapat memberikan dampak ekonomi yang negatif dengan penurunan kuantitas dan kualitas dari produk yang dihasilkan (Kevan dan Phillips 2001; Potts et al. 2016) selain dampak negatif pada agroekosistem (Suttle 2003). Di sisi lain, salah satu perkembangan teknologi pada sistem pertanian yang diterapkan di Indonesia adalah teknologi rumah kaca yang menempatkan tanaman pada satu struktur bangunan yang memungkinkan pengendalian faktor iklim lokal untuk melindungi dari dampat merugikan lingkungan maupun hama. Akan tetapi, kondisi ini menyebabkan tanaman pada rumah kaca, yang umumnya merupakan tanaman produksi bernilai ekonomi tinggi, tidak mendapatkan akses jasa penyerbukan yang krusial bagi produksi biomasa yang dipanen.

Berdasarkan hal ini, maka dibutuhkan agen penyerbuk yang terdomestikasi untuk meningkatkan jasa penyerbukan pada sistem pertanian lokal dengan serangga lokal sebagai pilihan terbaik terkait dengan kemampuan adaptasi dan dampak yang diberikan pada kesetimbangan ekosistem lokal. Salah satu serangga yang berpotensi sebagai agen penyerbuk adalah lebah tidak bersengat lokal, Trigona (Tetragonula) laeviceps. Lebah tidak bersengat ini didomestikasi dengan tujuan untuk mendapatkan produk berupa madu dan propolis dengan nilai ekonomi tinggi. Pemanfaatan sebagai agen penyerbuk sangat minim dilakukan walaupun beberapa penelitian pada skala laboratorium telah menunjukkan bahwa kelompok lebah ini dapat berperan sebagai agen penyerbuk (Wulandari et al. 2017; Putra et al. 2017). Lebah ini dikenal dengan jarak terbang terbatas, ukuran koloni yang kecil dan tidak agresif, sehingga berpotensi untuk digunakan di rumah kaca yang memiliki luasan terbatas dengan aktivitas manusia tinggi. Walaupun demikian, relatif belum ditemukan penelitian terkait pemanfaatan serangga ini pada sistem produksi pertanian di rumah kaca maupun pada sistem tumpangsari di Indonesia. Oleh karena itu, tujuan penelitian ini adalah menguji efisiensi dari $T$. laeviceps sebagai agen penyerbuk pada sistem pertanian tertutup di dalam rumah kaca. Pada penelitian ini digunakan dua tanaman dari kelompok famili yang berbeda yaitu buncis (Phaseolus vulgaris L.) dan tomat (Solanum lycopersicum L.), yang ditanam secara tumpangsari dan merupakan dua tanaman unggulan produksi sayuran Jawa Barat, sebagai objek dari penelitian. Data kemampuan penyerbukan dari serangga ini selanjutnya dibandingkan dengan data penyerbukan alami yang terjadi pada sistem pertanian terbuka.

\section{BAHAN DAN METODE}

Bahan. Bahan yang digunakan pada penelitian ini adalah koloni $T$. laeviceps yang disimpan dalam bambu berbentuk silinder. Benih buncis yang digunakan adalah varietas Logawa dan benih tomat yang digunakan merupakan varietas Permata F1 yang keduanya diproduksi oleh PT East West Indonesia.

Pupuk yang digunakan adalah pupuk NPK dan pupuk daun yang dicampur dengan ekstrak kotoran hewan yang telah difermentasi dengan menggunakan molase dan Effective Microorganism. Pestisida hayati yang digunakan adalah Turex dengan dosis 1-2 gram/liter air. Fungisida yang digunakan antara lain Sidamec dengan konsentrasi $2.5 \mathrm{~mL} / 14$ liter air dan Mancozeb $D G$ dengan konsentrasi 10 gram/14 liter air

Lokasi. Penelitian dilakukan pada JanuariApril 2018 di wilayah kerja Kelompok Tani Karya Mandiri berlokasi di Desa Sukawangi, Kecamatan Pamulihan, Kabupaten Sumedang, Jawa Barat (itik koordinat $06^{\circ} 52^{\prime} 25.23^{\prime \prime} \mathrm{S}, 107^{\circ} 49^{\prime} 01,62^{\prime \prime} \mathrm{E}$ ) dengan ketinggian $968 \mathrm{mdpl}$ (Gambar 1).

Area penelitian berada di luar kawasan agroforestry tanaman kopi dengan iklim mikro selama penelitian yang diamati meliputi suhu udara berkisar antara $18-26^{\circ} \mathrm{C}$ dengan kelembapan udara antara $67-92 \%$, kecepatan angin $7-11 \mathrm{~km} / \mathrm{j}$ dan intensitas cahaya berkisar 2690-12060 Lux. Hasil analisis tanah pada lokasi penelitian menunjukkan bahwa pH tanah bernilai 4.64 (sangat masam), kadar C-organik $2.06 \%$ (sedang), N-total $0.23 \%$ (sedang), $\mathrm{C} / \mathrm{N}$ rasio 9 (rendah), $\mathrm{P}_{2} \mathrm{O}_{5}$ Bray 16.19 ppm $\mathrm{P}$ (sangat tinggi), $\mathrm{K}_{2} \mathrm{O} \mathrm{HCl} \mathrm{25 \%} \mathrm{(tinggi),} \mathrm{kadar}$ air $31.54 \%$, dan bulk density sebesar $0.85 \mathrm{~g} / \mathrm{cm}^{3}$.

\section{Prosedur Budidaya.}

Persiapan Media Tanam. Tanah diolahmenggunakan cangkul dan traktor dengan kedalaman sekitar $30 \mathrm{~cm}$. Selanjutnya dibuat bedengan dengan lebar $1 \mathrm{~m}$, panjang $12 \mathrm{~m}$, tinggi bedengan berkisar $20-30 \mathrm{~cm}$, dan jarak antar bedengan sekitar $50 \mathrm{~cm}$. Mulsa dipasang pada bedengan sebelum dilakukan penanaman dengan tujuan untuk menekan pertumbuhan gulma. Lubang tanam

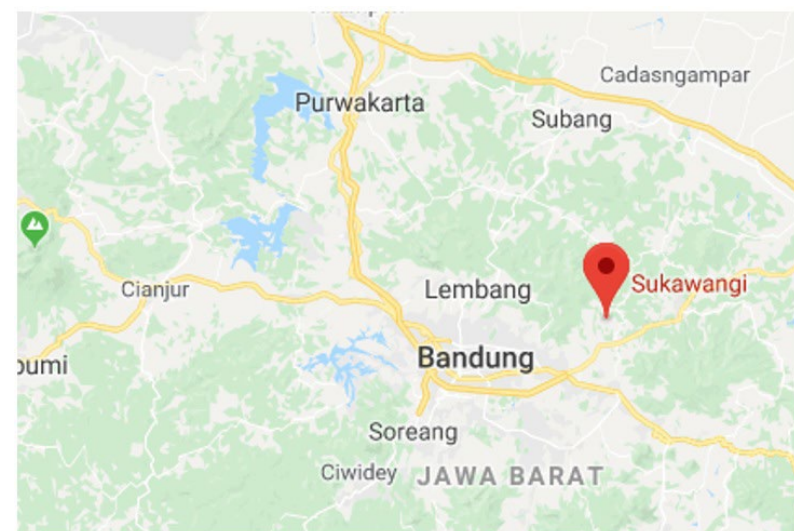

Gambar 1. Lokasi penelitian 
dibuat pada mulsa dengan jarak tanam $70 \times 30 \mathrm{~cm}$ menggunakan tugal (Gambar 2).

Penanaman. Benih buncis langsung ditanam pada lubang tanam yang telah dibuat, sedangkan benih tomat disemai terlebih dahulu selama 15 hari sebelum ditanam di lahan. Penanaman dilakukan di luar greenhouse pada kelompok kontrol sedangkan pada kelompok perlakukan dilakukan di dalam greenhouse. Benih tomat disemai di dalam pot persemaian yang berisi campuran tanah dengan arang sekam $(1: 1 \mathrm{~b} / \mathrm{b})$. Benih tomat yang telah berumur 2 minggu dan memiliki helai daun dipindahkan ke lubang tanam. Satu lubang tanam ditanami 1 bibit. Penanaman dilakukan pada pagi hari untuk mencegah kematian pada bibit. Tanaman buncis dan tomat ditanam menggunakan pola polikultur dengan jarak tanam 60 × $30 \mathrm{~cm}$ (Gambar 3). Jika terdapat benih yang tidak tumbuh, maka dilakukan penyulaman dengan benih yang baru. Penyulaman dilakukan di bawah umur 7 hari setelah tanam, agar


Gambar 2. (a) Proses persiapan lahan dan (b) bedengan yang telah siap ditanam

\begin{tabular}{|c|c|c|c|}
\hline PTO1 & PBO1 & PTT1 & PBT1 \\
\hline $\mathrm{PBO} 2$ & PTO2 & PBT2 & PTT2 \\
\hline PTO3 & $\mathrm{PBO} 3$ & PTT3 & PBT3 \\
\hline PBO4 & PTO4 & PBT4 & PTT4 \\
\hline PTO5 & PBO5 & PTT5 & PBT5 \\
\hline PBO6 & PTO6 & PBT6 & PTT6 \\
\hline PTO7 & $\mathrm{PBO} 7$ & PTT7 & PBT7 \\
\hline PBO8 & PTO8 & PBT8 & РTT8 \\
\hline PTO9 & PBO9 & РTT9 & РВТ9 \\
\hline PBO10 & PTO10 & PBT10 & PTT10 \\
\hline \multicolumn{2}{|c|}{ Kon } & \multicolumn{2}{|c|}{ Perlakuan } \\
\hline \multicolumn{2}{|c|}{ PTO $=$ Tomat } & \multicolumn{2}{|c|}{ PTT $=$ Tomat } \\
\hline \multicolumn{2}{|c|}{$\mathrm{PBO}=$ Buncis } & \multicolumn{2}{|c|}{$\mathrm{PBT}=$ Buncis } \\
\hline
\end{tabular}
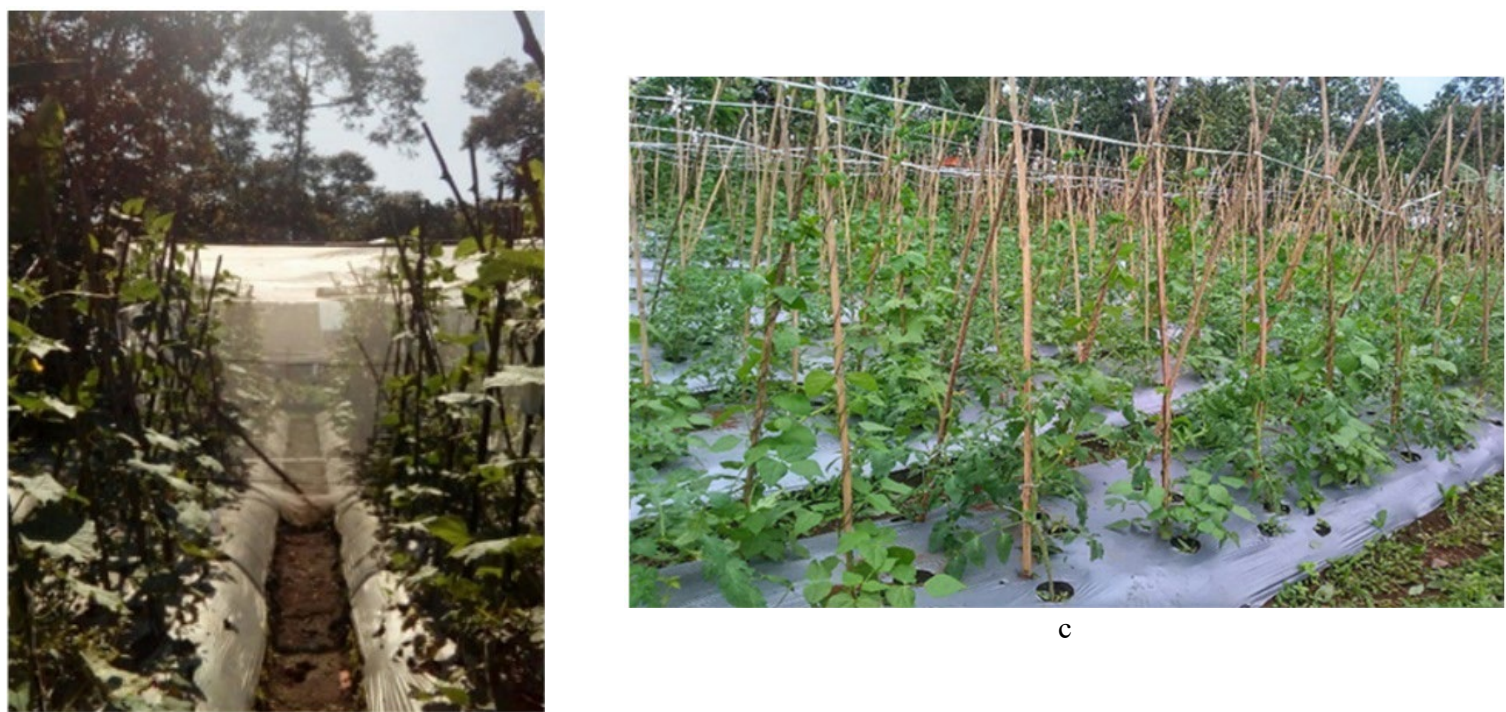

b

Gambar 3. (a) Denah plot perlakuan pada kelompok kontrol dan perlakuan, (b) greenhouse yang diletakkkan bersebelahan dengan (c) lokasi penanaman di luar greenhouse (kelompok kontrol) Plot perlakuan ditempatkan di dalam greenhouse. Greenhousenya tidak tampak 
pertumbuhan bibit penyulaman tidak berbeda jauh dengan tanaman yang telah ditanam sebelumnya.

Perlakuan Penyerbukan. Perlakuan penyerbukan terdiri dari penyerbukan terbuka dan penyerbukan di dalam greenhouse oleh $T$. laeviceps. Penyerbukan terbuka dilakukan dengan cara membiarkan bunga buncis dan bunga tomat terbuka untuk memberikan akses kebebasan polinator liar maupun penyerbukan oleh angin. Penyerbukan dengan spesies $T$. laeviceps dilakukan dengan cara mengintroduksi 3 buah koloni $T$. laeviceps (sekitar 500 lebah per koloni) yang disimpan dalam bambu berbentuk silinder ke dalam greenhouse yang telah dibuat. Setiap koloni diletakkan dalam radius 2 meter di setiap bedengan tanaman sebelum bunga muncul. Tiap perlakuan diulang 3 kali.

Greenhouse berukuran $12 \times 3 \times 2.5 \mathrm{~m}^{3}$ dibuat dari material bambu dan kain tile kasar (nylon mesh) dengan ukuran pori-pori sebesar $1 \mathrm{~mm}$ untuk menghindari kunjungan polinator selain $T$. laeviceps ke bunga buncis, mentimun, dan tomat. Setiap perlakuan terdiri dari 10 tanaman per komoditas tanaman yang telah dipilih secara acak (Gambar 3).

Frekuensi Kunjungan Lebah. Pengamatan kunjungan lebah dilakukan saat cuaca cerah dari pukul 08.00-16.00 WIB. Jumlah bunga yang diamati frekuensi kunjungan lebah yaitu sebanyak 10 bunga setiap tanaman per perlakuan. Setiap perlakuan terdiri dari 10 tanaman yang dipilih secara acak. Total bunga buncis dan tomat yang diamati adalah 200 bunga pada tiap perlakuan penyerbukan terbuka dan penyerbukan dengan T. laeviceps. Flower handling time dan foraging rate diamati untuk setiap agen penyerbuk yang mengunjungi bunga buncis, dan bunga tomat pada setiap perlakuan.

Foraging rate merupakan banyaknya bunga yang dikunjungi lebah selama satu menit dengan membagi waktu 60 detik dengan rata-rata waktu kunjungan atau banyaknya bunga yang dikunjungi dalam satu kali kunjungan. Visitation rate dapat diperoleh dengan menghitung persentase dari total kunjungan yang dilakukan oleh polinator yang ditemukan pada saat mengunjungi beberapa bunga buncis, dan bunga tomat. Flower handling time merupakan lama waktu serangga mengunjungi satu bunga (detik/bunga) (Klein et al. 2003).

Efisiensi Penyerbukan. Setiap bunga dari tanaman yang diamati ditandai dengan menggunakan label berukuran $2 \times 1 \mathrm{~cm}$ sebelum berbuah. Bunga yang ditandai adalah bunga yang belum mekar. Setelah bunga rontok dan menjadi bakal buah, dihitung persentase efisiensi polinasi dari setiap perlakuan penyerbukan.

$$
\begin{gathered}
\text { Persentase Efisiensi } \\
\text { Polinasi }
\end{gathered}=\frac{\begin{array}{c}
\text { Jumlah total bunga yang } \\
\text { menghasilkan buah }
\end{array}}{\begin{array}{c}
\text { Jumlah total bunga } \\
\text { yang diamati }
\end{array}} \times 100 \%
$$

Panen dan Pascapanen. Buncis varietas Logawa dipanen 48-54 hari setelah tanam. Ciri-ciri buncis yang siap panen adalah warna polong agak muda, permukaan kulit kasar, dan biji polong belum menonjol. Panen buncis dilakukan setiap 2-3 hari hingga 7 kali panen.

Buah tomat varietas permata dipanen 60-70 HST. Ciri buah tomat yang siap dipanen yaitu berwarna hijau, oranye, atau merah dengan bentuk buah tidak terlalu keras. Buah tomat dapat dipanen 10-15 kali per musim tanam dengan selang waktu tiap 2-3 hari (Maskar dan Gafur 2006).

Bobot Buah, Panjang Buah, dan Diameter Buah. Bobot segar buah buncis, mentimun, dan tomat setiap perlakuan yang telah dipanen selanjutnya ditimbang di Laboratorium Biomassa, Labtek 1A, SITH ITB Jatinangor menggunakan timbangan digital. Diameter buah diukur dengan menggunakan jangka sorong (digital caliper). Panjang buah diukur dengan menggunakan meteran.

Analisis Data. Data yang diamati terdiri dari visitation, foraging rate, flower handling time, bobot buah, panjang buah, serta diameter buah. Data yang diperoleh selanjutnya dianalisis menggunakan software SPSS 22.0 dengan uji independent samples T-test pada tingkat kepercayaan $95 \%(\alpha=0.05)$ untuk data yang homogen dan berdistribusi normal. Data yang tidak berdistribusi normal dan tidak homogen selanjutnya dianalisis dengan uji non parametrik Mann Whitney.

\section{HASIL}

Perbandingan Aktivitas Serangga Penyerbuk Alami dengan T. laeviceps pada Tanaman Uji. Pada kelompok tanaman kontrol, hanya lebah madu asia (Apis cerana) yang ditemukan mengunjungi bunga dari objek penelitian, sehingga pada penelitian ini hanya data kunjungan dari lebah ini yang ditampilkan. Di sisi lain, tidak ditemukan kunjungan lebah pada bunga tomat baik pada kelompok kontrol maupun perlakuan, sehingga seluruh data kunjungan serangga penyerbuk hanya berasal dari tanaman buncis.

Secara garis besar jumlah $A$. cerana yang mengunjungi bunga buncis lebih banyak dibandingkan $T$. laeviceps. Selain itu A. cerana yang diamati menghabiskan waktu lebih lama pada bunga walaupun jumlah bunga yang dikunjungi per menit jauh lebih rendah (Tabel 1).

Aktivitas harian dari A. cerana dan T. laeviceps terdapat perbedaan saat mengunjungi bunga buncis. Apis cerana memulai kunjungan ke bunga buncis lebih pagi walaupun total masa kunjungan per hari relatiflebih rendah dibandingkan T. laeviceps (Gambar 4). Aktivitas A. cerana dalam mencari pakan lebih awal dari T. laeviceps yaitu dimulai pada pukul 08.00 dan diakhiri pada pukul 12.00. Waktu kunjungan $A$. 
cerana paling lama pada pukul 08.00-09.00 kemudian pada pukul 11.00-12.00. Rata-rata waktu kunjungan perbunga $A$. cerana pada bunga buncis lebih lama dibandingkan T. laeviceps, walaupun jumlah bunga yang dikunjungi per menit jauh lebih rendah (Gambar 4).

Aktivitas kunjungan T. laeviceps pada bunga buncis dimulai pukul 09.00 dengan puncak kunjungan dicapai pada pukul 11.00-12.00. Tingkat flowering handling time tertinggi oleh $T$. laeviceps tercatat pada pukul 10.00-11.00 (9.86 detik) diikuti dengan kunjungan pada pukul 09.00-10.00 dan 11.00-12.00 (Gambar 4).

Efisiensi Penyerbukan. Hasil penelitian ini menunjukkan bahwa tidak terdapat perbedaan pada efisiensi penyerbukan pada bunga buncis dan tomat antara kelompok kontrol dan kelompok perlakuan.

Tabel 1. Aktivitas kunjungan lebah pada tanaman buncis

\begin{tabular}{|c|c|c|c|}
\hline $\begin{array}{l}\text { Serangga } \\
\text { penyerbuk }\end{array}$ & $\begin{array}{l}\text { Flower handling } \\
\text { time (detik) }\end{array}$ & $\begin{array}{l}\text { Foraging rate } \\
\text { (bunga per } \\
\text { menit) }\end{array}$ & $\begin{array}{l}\text { Visitation } \\
\text { rate (bunga/ } \\
\text { penyerbuk) }\end{array}$ \\
\hline$\overline{\text { Apis cerana }}$ & $14.92 \pm 11.09 \mathrm{a}$ & $2.67 \pm 2.08 \mathrm{a}$ & $50.49 \pm 2.64 a$ \\
\hline $\begin{array}{l}\text { Trigona } \\
\quad \text { laeviceps }\end{array}$ & $6.81 \pm 2.4 \mathrm{a}$ & $4.25 \pm 1.93 \mathrm{a}$ & $49.51 \pm 2.12 \mathrm{a}$ \\
\hline
\end{tabular}


Pada tanaman tomat yang ditempatkan di bagian luar greenhouse (kelompok kontrol) memiliki tingkat efisiensi penyerbukan yang lebih baik dibandingkan tanaman tomat yang ditempatkan di dalam greenhouse (Tabel 2).

Kualitas Produk. Tidak terdapat perbedaan signifikan pada kualitas dari buah buncis antara kelompok kontrol dan perlakuan walaupun ukuran dari variabel yang diamati relatif lebih besar (Tabel 3). Hal berbeda ditemukan pada buah tomat dimana kelompok perlakuan yang memiliki ukuran diameter, panjang, dan berat buah lebih besar dibandingkan buah tomat pada kelompok kontrol walaupun tidak terdapat perbedaan yang signifikan antar kedua kelompok (Tabel 3). Bila tidak berbeda nyata, artinya antara perlakuan memberikan respon yang sama, maka tidak perlu disebutkan "lebih baik".

\section{PEMBAHASAN}

Aktivitas Serangga Penyerbuk. Pada penelitian ini tidak ditemukan serangga yang mengunjungi bunga tomat selama masa bunga mekar. Hasil ini berbeda dengan hasil penelitian oleh Widhiono
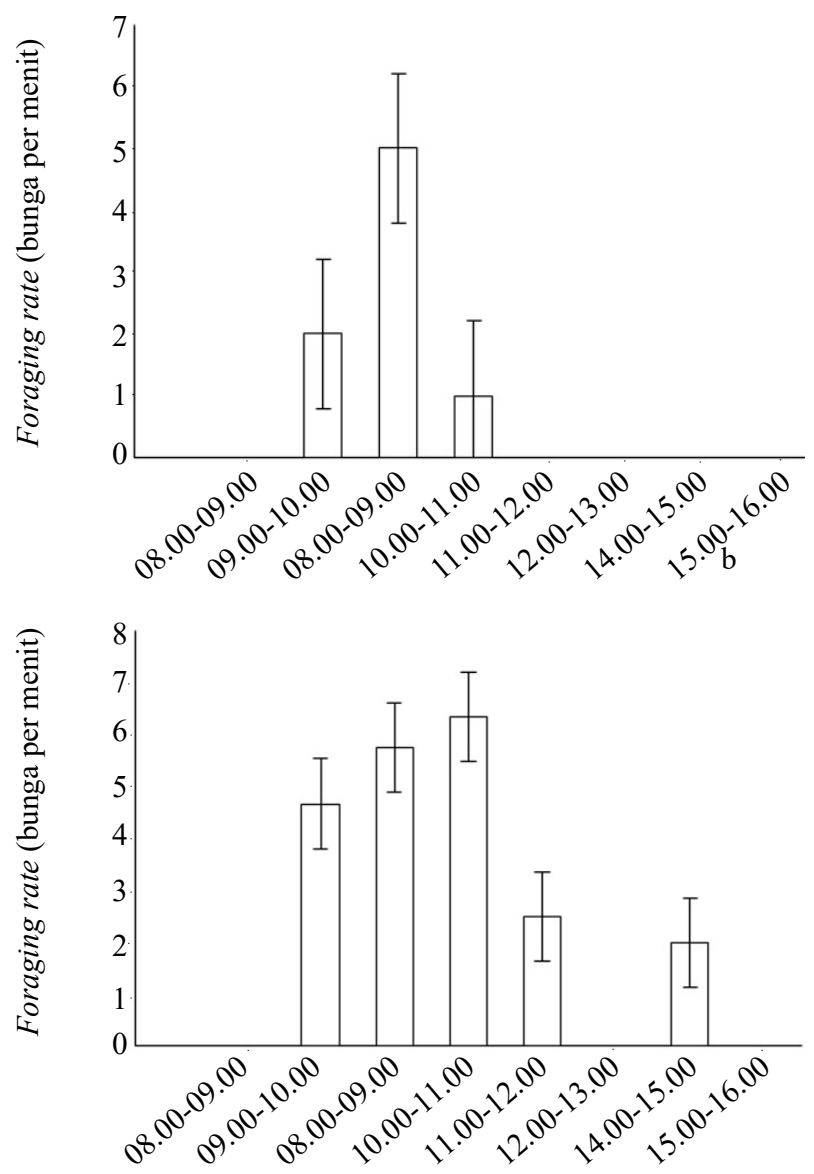

Gambar 4. Aktivitas harian dari flowering handling time dan foraging rate dari (a) Apis cerana dan (b) Tetragonula laeviceps pada tanaman buncis 
Tabel 2. Efisiensi penyerbukan antar perlakuan

\begin{tabular}{llc}
\hline \multirow{2}{*}{ Perlakuan } & \multicolumn{2}{c}{ Efisiensi penyerbukan (\%) } \\
\cline { 2 - 3 } & Buncis & Tomat \\
\hline Kontrol & $41 \pm 21.19 \mathrm{a}$ & $84 \pm 15.62 \mathrm{a}$ \\
$\begin{array}{c}\text { Greenhouse } \\
\text { (perlakuan) }\end{array}$ & $41 \pm 21.19 \mathrm{a}$ & $71 \pm 26.25 \mathrm{a}$ \\
\hline $\begin{array}{l}\text { huruf yang sama pada kolom yang sama } \\
\text { perlakuan tidak berbeda nyata (uji T, } \mathrm{p}<0.05)\end{array}$ &
\end{tabular}

Tabel 3. Perbandingan diameter, panjang dan bobot buah buncis dan tomat antara kelompok kontrol dan perlakuan

\begin{tabular}{cllc}
\hline \multirow{2}{*}{ Parameter } & \multirow{2}{*}{ Kelompok } & \multicolumn{2}{c}{ Tanaman } \\
\cline { 3 - 4 } & & \multicolumn{1}{c}{ Buncis } & Tomat \\
\hline Diameter & Kontrol & $7.2 \pm 1.03 \mathrm{a}$ & $28.34 \pm 4.08 \mathrm{a}$ \\
buah $(\mathrm{mm})$ & Perlakuan & $6.9 \pm 1.42 \mathrm{a}$ & $29.45 \pm 5.03 \mathrm{a}$ \\
Panjang buah & Kontrol & $14.47 \pm 2.22 \mathrm{~b}$ & $29.85 \pm 4.23 \mathrm{a}$ \\
$(\mathrm{cm})$ & Perlakuan & $12.01 \pm 2.37 \mathrm{~b}$ & $32.65 \pm 4.98 \mathrm{a}$ \\
Bobot buah & Kontrol & $7.07 \pm 2.43 \mathrm{a}$ & $14.76 \pm 6.77 \mathrm{a}$ \\
$(\mathrm{g})$ & Perlakuan & $5.20 \pm 2.53 \mathrm{a}$ & $17.75 \pm 5.95 \mathrm{a}$ \\
\hline huruf yang sama pada kolom yang sama & menunjukkan \\
perlakuan tidak berbeda nyata (uji T, $\mathrm{p}<0.05)$ &
\end{tabular}

dan Sudiana (2016) dan Indraswari et al. (2016) yang melaporkan bahwa lebah tidak bersengat dari kelompok Tetragonula (Trigona) merupakan salah satu serangga pengunjung bunga tomat. Perbedaan ini kemungkinan berkaitan dengan lokasi dari penelitian tersebut yang berada di sekitar hutan, sehingga hutan dapat berperan sebagai sumber bunga bagi serangga penyerbuk. Kondisi lokasi penelitian yang terdapat di sekitar daerah pertanian tanpa keberadaan hutan dapat menurunkan keragaman dari serangga yang mengunjungi bunga sebagaimana ditunjukkan pada penelitian serupa di lahan pertanian yang melaporkan bahwa lebah tidak bersengat tidak mengunjungi bunga tomat (Indraswari et al. 2016). Hal lain yang mungkin dapat menjelaskan mengapa $T$. laeviceps tidak mengunjungi bunga tomat di dalam rumah kaca adalah keberadaan bunga buncis yang kemungkinan mempunyai attractant yang kuat berupa nektar (Douka dan Fohouo 2013), sedangkan jumlah nektar yang dihasilkan oleh bunga tomat tidak memiliki nilai bagi serangga karena jumlah yang sangat kecil (McGregor 1976).

Waktu yang dihabiskan $T$. laeviceps pada bunga buncis cukup untuk melakukan proses penyerbukan yang diduga terjadi saat serangga menghabiskan waktu lebih dari 3 detik pada struktur reproduktif bunga (Putra et al. 2014). Flowering handling time yang lebih tinggi pada $A$. cerana kemungkinan berkaitan dengan tingkat kebutuhan koloni yang lebih besar dibandingkan T. laeviceps yang memiliki ukuran tubuh dan koloni jauh lebih kecil.

Pada penelitian ini, kami mendapatkan waktu aktif dari A. cerana adalah pada pukul 08.00-12.00 yang serupa dengan hasil penelitian Kahono (1992) dan Reddy et al. (2015) sedangkan waktu aktif $T$. laeviceps dimulai pada pukul 09.00 dengan puncak kunjungan pada pukul 11.00-12.00 yang serupa dengan hasil penelitian Putra et al. (2017).

Perbedaan pada foraging rate antara $A$. cerqna dan $T$. laeviceps dapat dipengaruhi oleh kondisi lingkungan yang memengaruhi kandungan gula pada nektar sebagai sumber energi yang dikoleksi oleh lebah (Ruslan et al. 2015), kebutuhan energi untuk mendapatkan makanan tersebut (Tan et al. 2015), dan kebutuhan koloni (yang dapat dipengaruhi oleh jumlah anggota dan usia koloni) (Hendriksma et al. 2019). Lebah sosial (seperti $A$. cerana dan $T$. laeviceps) memiliki perilaku dimana terdapat pertimbangan antara jumlah energi yang dihabiskan dengan jumlah energi yang dapat dibawa kembali ke koloni (dalam bentuk nektar), dikenal sebagai honeybee economics (Stabentheiner dan Kovac 2016). Jumlah anggota koloni yang lebih besar pada A. cerana dapat meningkatkan agresivitas dan penghematan energi dalam proses pencarian makan (Putra et al. 2014) yang menyebabkan lebah madu memiliki kecenderungan untuk mengunjungi hanya sebagian bunga dengan reward lebih tinggi dibandingkan menghabiskan energi untuk mengunjungi banyak bunga. Di sisi lain, aktivitas kunjungan $A$. cerana dan T. laeviceps sangat berkaitan dengan kondisi mikroklimat di lapangan dan terdapat perbedaan di antara kedua jenis serangga ini. Pada kelompok Apidae (Famili dimana $A$. cerana tergabung), aktivitas terbang berkurang pada suhu rendah dan kelembapan tinggi, karena memerlukan energi yang besar untuk memanaskan suhu toraks sampai $35^{\circ} \mathrm{C}$ (suhu ideal untuk mengaktifkan otot terbang) (Yao et al. 2006), kondisi yang dapat mengurangi "selisih energi" yang dapat dibawa ke koloni. Hal ini dapat menjelaskan mengapa aktivitas dimulai pada saat suhu relatif lebih hangat. Aktivitas A. cerana berhenti pada pukul 12.00 kemungkinan terkait dengan suplai nektar yang telah menurun, yang sayangnya tidak diperiksa pada penelitian ini dan dapat menjadi dasar dari penelitian lanjutan. Aktivitas T. laeviceps dimulai pada waktu yang sama dengan tingkat kunjungan (foraging rate) lebih tinggi dan waktu aktivitas lebih panjang. Aktivitas yang lebih padat dan awal pada T. laeviceps didua berkaitan dengan ukuran tubuh yang lebih kecil sehingga lebih mudah untuk mencapai panas tubuh yang dibutuhkan (Pereboom dan Biesmeijer 2003) selain kebutuhan akan nektar yang lebih kecil.

Efisiensi Penyerbukan. Penelitian ini menunjukkan bahwa proses penyerbukan yang dibantu dengan serangga terbukti meningkatkan produktivitas tanaman, selaras dengan hasil penelitian Douka dan Fohouo (2013) dan Ramos 
et al. (2018), apabila dibandingkan dengan hasil penelitian Kingha et al. (2012) yang melaporkan bahwa ketidakhadiran serangga penyerbuk membatasi tingkat penyerbukan bunga pada nilai 20-26.67\%. Data penelitian menunjukkan tidak terdapat perbedaan antara kesuksesan penyerbukan antara tanaman buncis yang menunjukkan potensi dari T. laeviceps sebagai agen penyerbuk buncis terutama pada daerah-daerah dengan tingkat keanekaragaman dan kelimpahan serangga penyerbuk yang rendah atau pada greenhouse dimana akses terhadap penyerbuk alami terbatas.

Penelitian ini juga menunjukkan bahwa bunga tomat tidak mendapatkan kunjungan serangga yang kemungkinan berkaitan dengan reward yang diberikan oleh bunga tomat. Bunga tomat tidak menghasilkan nektar yang merupakan sumber energi utama yang dikumpulkan oleh $A$. cerana dan T. laeviceps. Hal serupa dilaporkan oleh Herren dan Ochieng (2011) bahwa proses penyerbukan pada tomat kurang mendapatkan bantuan lebah lokal yang dominan di daerah tropis (dalam kasus penelitian ini adalah A. cerana dan T. laeviceps). Beberapa penelitian di Indonesia melaporkan bahwa penyerbukan tomat dapat dibantu oleh serangga-serangga penyerbuk liar, seperti lebah dari kelompok Apidae (contoh: Xylocopa confusa dan Amegilla cyrtandrae) dan Megachilidae (contoh: Lasioglossum leucozonium), yang sangat ditentukan oleh kualitas dari lingkungan sekitar daerah pertanian (Widhiono dan Sudiana 2015; Indraswari et al. 2016). Walaupun tidak mendapatkan kunjungan serangga, tanaman ini tetap menghasilkan buah. Hal ini selaras dengan hasil penelitian Mayer (2000) yang menunjukkan bahwa tingkat ketergantungan tomat pada serangga dalam proses penyerbukan hanya $0.07 \%$ hingga $12 \%$. Hal ini disebabkan karakteristik dari bunga tomat yang bersifat sebagai bunga hermaprodit dengan anther harus divibrasi untuk melepaskan serbuk sari sehingga memungkinkan proses penyerbukan terjadi (Buchmann 1983). Studi menunjukkan bahwa proses vibrasasi dapat terjadi dengan bantuan serangga (Bashir et al. 2018) dan angin (ViniciusSilva et al. 2017). Dengan minimnya kunjungan serangga, maka keberadaan angin menjadi faktor penting dalam produksi buah pada tanaman tomat. Hal ini dapat menjelaskan mengapa tingkat penyerbukan pada kelompok kontrol (ditanam di luar greenhouse) lebih baik dibandingkan di dalam greenhouse dimana tanaman relatif lebih terlindungi dari pergerakan angin.

Kualitas Produk. Penelitian ini tidak menunjukkan perbedaan signifikan pada kualitas buncis dan tomat pada kedua kelompok buat walaupun perbedaan efek dari model budidaya pada kedua tanaman ini. Pada tanaman buncis, kualitas terbaik ditemukan pada kelompok buncis yang ditanam pada greenhouse sedangkan pada tomat pada kelompok tomat yang ditanam pada lahan terbuka. Hasil pada buncis sejalan dengan hasil dari Ngelenzi et al. (2017) yang menunjukkan efek positif dari budidaya buncis di dalam greenhouse yang terkait dengan perlindungan terhadap faktor lingkungan dan serangan hama sedangkan hasil pada tomat sejalan dengan hasil dari Chapagain dan Wiesman (2004) yang melaporkan kualitas tomat yang lebih baik pada sistem budidaya di lahan terbuka yang dapat terkait dengan kesuksesan proses penyerbukan (Bashir et al. 2018).

\section{KESIMPULAN}

Penelitian ini menunjukkan beberapa hal penting terkait dengan peran dari serangga penyerbuk pada sistem budidaya tumpangsari antara buncis dan tomat. Pertama, model budidaya tumpangsari antara buncis dan tomat tidak menarik kedatangan dari serangga penyerbuk liar pada sistem budidaya sehingga dibutuhkan tanaman penarik serangga penyerbuk. Kedua, koloni $T$. laeviceps dapat diaplikasikan dalam sistem budidaya buncis di dalam greenhouse sebagai agen penyerbuk yang memiliki efisiensi sama dengan serangga penyerbuk alami. Ketiga, terdapat fenomena minimnya populasi serangga penyerbuk pada sistem pertanian di beberapa lokasi yang terpisah dari daerah alami yang berpotensi menyebabkan produktivitas lahan tidak mencapai potensi terbaiknya, hal yang dapat menjadi dasar dari penelitia lanjutan di masa datang.

\section{UCAPAN TERIMA KASIH}

Penulis mengucapkan terima kasih kepada Pak Yoyo Kusnadi yang telah membantu selama proses budidaya. Sebagian penelitian ini menggunakan peralatan yang dibiayai oleh Riset ITB 2011 dan Riset Unggulan Terapan Perguruan Tinggi 2018 yang diterima oleh penulis korespondensi.

\section{DAFTAR PUSTAKA}

Adiyoga W, Suherman R, Soetiarso TA. 2004. Profil Komoditas Tomat. Jakarta:PAATP-Puslitbang Hortikultura.

Biesmeijer JC, Roberts SPM, Reemer M, Ohlemuller R, Edwards M, Peeters T, Schaffers AP, Potts SG, Kleukers R, Thomas CD, Settele J, Kunin WE. 2006. Parallel declines in pollinators and insect-pollinated plants in Britain and the Netherlands. Science 313:351-354.

[BPS] Badan Pusat Statistik. 2018. Produksi Tanaman Sayuran. Tersedia di https://www.bps.go.id/site/resultTab [diakses 13 Maret 2018]

Bashir MA, Alvi MA, Khan KA, Rehmani MIA, Ansari MJ, Atta S, Ghramh HA, Batool T, Tariq M. 2018. Role of pollination in yield and physicochemical properties of tomatoes (Lycopersicon esculentum). Saudi J Biol Sci 25:1291-1297. 
Breeze TD, Gallai N, Garibaldi LA, Li XS. 2016. Economic measures of pollination services: shortcomings and future directions. Trends Ecol Evol 31:927-939.

Buchmann SL. 1983. Buzz pollination in angiosperms. Dalam: Jones CE, Little RJ (eds). Handbook of Experimental Pollination Biology. New York: Scientific and Academic Editions. p 73-113.

Cameron SA, Lozier JD, Strange JP, Koch JB, Cordes N, Solter LF, Griswold TL. 2011. Patterns of widespread decline in North American bumble bees. PNAS 108:662-667.

Carvalheiro LG, Kunin WE, Keil P, Aguirre-Gutiérrez J, Ellis WN, Fox R, Groom Q, Hennekens S, Van Landuyt W, Maes D, Van de Meutter F, Michez D, Rasmont P, Ode B, Potts SG, Reemer M, Roberts SP, Schaminée J, WallisDeVries MF, Biesmeijer JC. 2013. Species richness declines and biotic homogenization have slowed down for NW-European pollinators and plants. Ecol Lett 16:870-878.

Chapagain BP, Weisman Z. 2004. Effect of potassium magnesium chloride in the fertigation solution as partial source of potassium on growth, yield, and quality of greenhouse tomato. J Sci Hort 99:279-288.

Douka C, Fohouo FNT. 2013. Foraging and pollination behavior of Apis mellifera adansonii L. (Hymenoptera, Apidae) on Phaseolus vulgaris (Fabaceae) flowers at Maroua (Cameroon). Int Res J Plant Sci 4:45-54.

Gerling D, Velthuis HHW, Hefetz A. 1989. Bionomics of the large carpenter bee Xylocopa pubescens and its implications for the evolution of sociality. Annu Rev Entomol 2:123-128.

Hendriksma HP, Toth AL, Shafir S. 2019. Individual and colony level foraging decisions of bumble bees and honey bees in relation to balancing of nutrient needs. Front Ecol Evol 7:1-12.

Herren BG, Ochieng AO. 2011. Role of native bees and natural habitats in Eggplant (Solanum melongena) pollination in Kenya. Agr Ecosyst Environ 127:31-36.

Indraswari AGM, Atmowidi T, Kahono S. 2016. Keanekaragaman, aktivitas kunjungan, dan keefektifan lebah penyerbuk pada tanaman tomat (Solanum lycopersicum L:Solanaceae). $J$ Entomol Indonesia 13:21-29.

Jacquemin F, Violle C, Rasmont P, Dufrêne M. 2017. Mapping the dependency of crops on pollinators in Belgium. One Ecosystem 2:e13738.

Kahono S. 1992. Pengamatan sumber pakan dan aktivitas lebah madu dan aktifitas lebah madu Asia (Apis cerana F.) untuk menunjang budidaya di Desa Pasir Eurih, Kecamatan Ciomas, Kabupaten Bogor, Jawa Barat. Buletin Peter 16:120-126.

Kevan PG, Phillips TP. 2001. The economic impacts of pollinator declines: an approach to assessing the consequences. Conserv Ecol 5:1-17.

Kingha BMT, Fohouo FNT, Ngakou A, Bruckner D. 2012. Foraging and Pollination Activities of Xylocopa olivacea (Hymenoptera, Apidae) on Phaseolus vulgaris (Fabaceae) Flowers at Dang (Ngaoundere-Cameroon). J Agr Rural Dev 4:330-339.

Klein AM, Steffan-Dewenter I, Tscharntke T. 2003. Bee pollination and fruit set of Coffea arabica and Coffea canephore (Rubiaceae). Am J Bot 90:153-157.

Klein AM, Vaissière BE, Cane JH, Steffan-Dewenter I, Cunningham SA, Kremen C, Tscharntke T. 2007. Importance of pollinators in changing landscapes for world crops. Proc Biol Sci 274:303-313.

Maskar, Gafur S. 2006. Budidaya Tomat. Sulawesi Tengah:Balai Pengkajian Teknologi Pertanian Departemen Pertanian.

Mayer DF. 2000. Crop Pollination by Bees. New York:CABI Publishing.

McGregor SE. 1976. Insect Pollination of Cultivated Crop Plants. Washington:Agricultural Research Service.

Ngelenzi MJ, Mwanarusi S, Otieno OJ. 2017. Improving French Bean (PhaseolusVulgaris L.) pod yield and quality through the use of different coloured Agronet covers. Sustain Agri Res 6:63-72.
Pereboom JJM, Biesmeijer JC. 2003. Thermal constraints for stingless bee foragers: the importance of body size and coloration. Oecologia 137:42-50.

Potts SG, Biesmeijer JC, Kremen C, Neumann P, Schweiger O, Kunin WE. 2010. Global pollinator declines: trends, impacts and drivers. Trends Ecol Evol 25:345-353.

Potts SG, Imperatriz-Fonseca V, Ngo HT, Aizen MA, Biesmeijer JC, Breeze TD, Dicks LV, Garibaldi LA, Hill R, Settele J, Vanbergen AJ. 2016. Safeguarding pollinators and their values to human well-being. Nature 540:220-229.

Putra RE, Permana AD, Kinasih I. 2014. Application of Asiatic Honey Bees (Apis cerana) and Stingless Bees (Trigona laeviceps) as pollinator agents of Hot Pepper (Capsicum annuиm L.) at local Indonesia farm system. Psyche 2014:1-5.

Putra RE, Subagio J, Kinasih I, Permana AD, Rosmiati M. 2017. Pola kunjungan serangga liar dan efek penambahan koloni Trigona (Tetragonula) laeviceps Smith pada penyerbukan kabocha (Cucurbita maxima). JEntomol Indonesia 14:6979

Ramos DdL, Bustamante MMC, Silva FDdSe, Carvalheiro LG. 2018. Crop fertilization affects pollination service provision-common bean as a case study. PLOS ONE 13:e0204460

Reddy PV, Rashmi T, Verghese A. 2015. Foraging activity of Indian honeybee, Apis cerana in relation to ambient climate variables under tropical conditions. J Environ Biol 36:577-581.

Ricketts TH. 2004. Tropical forest fragments enhance pollinator activity in nearby coffee crops. Conserv Biol 18:12621271.

Ruslan W, Afriani, Miswan, Elijonnahdi, Nurdiyah, Sataral M, Fitrallisan, Fahri. 2015. Frekuensi kunjungan lebah Apis cerana dan Trigona sp. sebagai penyerbuk pada tanaman Brassica rapa. Online Journal of Natural Science 4:65-72.

Stabentheiner A, Kovac H. 2016. Honeybee economics: optimization for foraging in a variable world. Sci Rep $6: 1-7$.

Suttle KB. 2003. Pollinators as mediators of top-down effects on plants. Ecol Lett 6:688-694.

Tan K, Latty T, Dong S, Liu X, Wang C, Oldroyd BP. 2015. Individual honey bee (Apis cerana) foragers adjust their fuel load to match variability in forage reward. Sci Rep 5:1-7.

Tscharntke T, Klein AM, Kruess A, Steffan-Dewenter I, Thies C. 2005. Landscape perspectives on agricultural intensification and biodiversityecosystem service management. Ecol Lett 8:857-874.

Vinicius-Silva R, Parma DF, Tostes B, Arruda VM, Werneck MV.2017. Importance of bees in pollination of Solanum lycopersicum L. (Solanaceae) in open-field of the Southeast of Minas Gerais State, Brazil. Hoehnea 44:349-360.

Widhiono I, Sudiana E. 2015. Keragaman serangga penyerbuk dan hubunganya dengan warna bunga pada tanaman pertanian di lereng utara Gunung Slamet, Jawa Tengah. Biospecies 8:43-50.

Widhiono I, Sudiana E. 2016. Impact of distance from the forest edge on the wild bee diversity on the Northern Slope of Mount Slamet. Biosaintifika 8:148-154.

Winfree R, Williams NM, Gaines H, Ascher JS, Kremen C. 2008. Wild bee pollinators provide the majority of crop visitation across land-use gradients in New Jersey and Pennsylvania, USA. J Appl Ecol 45:793-802.

Wulandari AP, Atmowidi T, Kahono S. 2017. Peranan lebah Trigona laeviceps (Hymenoptera: Apidae) dalam produksi biji Kailan (Brassica oleracea var. alboglabra). J Agron Indonesia 45:197-204.

Yao YF, Bera S, Wang YF, Li CS. 2006. Nectar and pollen sources for honeybee (Apis cerana cerana Fabr.) in Qinglan mangrove area, Hainan Island, China. J Integr Plant Biol 48:1266-1273. 